\title{
NAIL AND BONE SURFACE AS INDICATORS OF ACUTE EXPOSURE TO FLUORIDE IN RATS
}

\author{
UNHA E SUPERFÍCIE ÓSSEA COMO INDICADORES DA EXPOSIÇÃO AGUDA EM RATOS
}

\author{
Marília Afonso Rabelo BUZALAF ${ }^{1}$, Myrna Maria LINARDI ${ }^{2}$, Juliane Guimarães de CARVALHO ${ }^{3}$, \\ Vanessa Eid da Silva CARDOSO ${ }^{4}$, Jaime Aparecido CURY ${ }^{5}$
}

\begin{abstract}
1- DDS, MSc, PhD, Associate Professor, Department of Biological Sciences, Bauru Dental School, University of São Paulo.
2- DDS, Graduate Student, Department of Biological Sciences, Bauru Dental School, University of São Paulo.

3- DDS, MSc, Graduate Student, Department of Biological Sciences, Bauru Dental School, University of São Paulo.

4- DDS, MSc, PhD, Graduate Student, Institute of Chemistry, University of São Paulo.

5- DDS, MSc, PhD, Chair Professor, Department of Physiological Sciences, Piracicaba Dental School, University of Campinas. Department of Biological Sciences, Bauru Dental School, University of São Paulo, Brazil.
\end{abstract}

Corresponding address: Dra. Marília Afonso Rabelo Buzalaf - Al. Octávio Pinheiro Brisolla, 9-75 - Bauru-SP - Brazil - Cep.: 17012-901 Email: mbuzalaf@fob.usp.br

Received: December 12, 2003 - Returned for modification: September 17, 2004 - Accepted: September 22, 2004

\begin{abstract}
This sudy evaluated the use of nails and bone surfaces as indicators of acute exposure to fluoride in rats. Six groups ( $\mathrm{n}=10 / \mathrm{f}$ grp), aged 70 days, received, by gastrogavage, single doses of sodium fluoride containing 10, 35, 45, 60, 75 and 90 mg fluoride/ $\mathrm{kg}$ body weight. The control group received deionized water. Two hours after fluoride administration, the rats were killed and their plasma, nails (halves near to the growth end) and femur were collected. Nail and plasma fluoride concentrations were analyzed with the electrode following HMDS-facilitated diffusion. Femur surface fluoride was removed from a circular area $\left(4.52 \mathrm{~mm}^{2}\right)$ by immersion in $0.5 \mathrm{M} \mathrm{HCl}$ for 15 seconds, buffered with TISAB and analyzed with the electrode. Data were analyzed by ANOVA and Tukey's test $(\mathrm{p}<0.05)$ and by linear regression $(\mathrm{p}<0.001)$. Average fluoride concentrations ranged from 55.4 to $91.5 \mathrm{mg} / \mathrm{g}$ for nails; from 0.019 to $6.937 \mathrm{mg} / \mathrm{mL}$ for plasma and from 617 to 2,394 mg/g for femur surface. Fluoride concentrations in nails from experimental groups were not different from control. Regarding plasma fluoride, all experimental groups differed from control, except the group that received the lowest dose. In respect to femur surface fluoride, only the group that received the highest dose differed from control. A strong correlation was found between plasma fluoride and the dose administered $(\mathrm{r}=0.736)$ and a medium correlation was found between femur surface and the dose administered $(\mathrm{r}=0.510)$. Data suggest that two hours after an acute fluoride administration, nails and femur surface are not good indicators of fluoride exposure.

Uniterms: Acute exposure; Biomarkers; Bone; Fluoride; Nails.
\end{abstract}

\section{RESUMO}

$E$ grupos (n=10/grp), com idade de 70 dias, receberam, por gastro-gavagem, doses únicas de fluoreto de sódio contendo 10, 35, 45, 60, 75 e $90 \mathrm{mg}$ flúor $/ \mathrm{kg}$ peso corpóreo. O grupo controle recebeu água deionizada. Duas horas após a administração de flúor, os ratos foram mortos e seu plasma, unhas (metades próximas à porção de crescimento) e fêmur foram coletados. As concentrações de flúor na unha e plasma foram analisadas com o eletrodo após difusão facilitada por HMDS. O flúor da superfície do fêmur foi removida de uma área circular $\left(4,52 \mathrm{~mm}^{2}\right)$ por imersão em $\mathrm{HCl}$ 0,5 M por 15 segundos, tamponado com TISAB (contendo $\mathrm{NaOH})$ e analisado com o eletrodo. Os dados foram analisados por ANOVA e teste de Tukey $(\mathrm{p}<0,05)$ e por regressão linear $(\mathrm{p}<0,001)$. As concentrações médias de flúor variaram de 55,4 a 91,5 mg/g para as unhas; de 0,019 a 6,937 mg/mL para o plasma e de 617 a 2.394 mg/g para a superfície do fêmur. A concentração de flúor nas unhas do grupo experimental não foi diferente do controle. Quanto ao flúor no plasma, todos os grupos experimentais diferiram do controle, exceto o grupo que recebeu a menor dose. Em respeito ao flúor na superfície do fêmur, apenas o grupo que recebeu a maior dose diferiu do controle. Uma forte correlação foi encontrada entre o flúor plasmático e a dose administrada $(r=0,736)$ e uma correlação média foi encontrada entre a superfície do fêmur e a dose administrada $(\mathrm{r}=0,510)$. Os dados sugerem que após duas horas de administração aguda de flúor, unhas e superfície do fêmur não são bons indicadores da exposição ao flúor.

Unitermos: Exposição aguda; Biomarcadores; Osso; Flúor; Unhas. 


\section{INTRODUCTION}

There are in the literature eventual reports of lethal intoxication due to acute exposure to fluoride salts $^{1,3,5,8,9,15,16,17,18,19,24,25,29}$. Most of such cases were accidental, but some of them involved suicide ${ }^{3,15,29}$. Thus, when death from fluoride poisoning is suspected, proper confirmation of the cause is usually necessary. Blood fluoride concentration is the most common test used for fluoride poisoning diagnosis. Blood fluoride levels can be as high as $19 \mathrm{ppm}^{19}$. When autopsy is carried out, high fluoride levels can also be found in kidney and urine ${ }^{29}$.

Nails have been used as biomarkers for chronic exposure to fluoride ${ }^{7,11,14,20,21,22,28}$. Whitford, et al. ${ }^{28}$ administered 3.0mg of fluoride daily during 30 days to an individual and observed a lag of time of 3.5 months before the nail fluoride concentrations increased. These authors proposed that fluoride enters fingernails via the matrix (growth portion) and not through the nail bed. Based on this, it is hypothesized that, if fluoride enters fingernails via the matrix, fluoride assay in nails growth portion could be used as an additional postmortem test in cases of poisoning due to acute fluoride ingestion. On the other hand, fluoride has a rapid and selective affinity for mineralized tissues in short time due to its uptake on bone crystal surfaces by iso-and hetero-ionic exchange $\mathrm{e}^{10}$.

Thus, the aim of the present study was to investigate whether rats exposed to acute doses of fluoride would have an increase of fluoride concentrations in their nails growth end and bone surfaces. If so, nails and/or bone surfaces fluoride analysis could be additional postmortem tests in cases of fluoride poisoning.

\section{MATERIALS AND METHODS}

Male Wistar rats were received from the Central Vivarium of Bauru Dental School (University of São Paulo, Bauru-SP) as weanlings and housed in pairs in plastic cages. The animals had free access to a regular diet (Purina, 25.9 ppm total fluoride soluble in 1.0M HCl) and deionized water. When the animals reached 70 days (body weight around $260 \mathrm{~g}$ ), they were randomly assigned to 7 groups (10 rats per group) that differed in the amount of fluoride (as sodium fluoride) received by single gastrogavage. Group 1 (control) received deionized water and groups 2, 3, 4, 5, 6 and 7 received 10, 35, 45, 60, 75 and $90 \mathrm{mg}$ fluoride/kg body weight, respectively (Table 1). Two hours after fluoride administration, the animals were anaesthetized with diethyl ether. A heart blood sample was collected into a lightly heparinized syringe for determination of plasma fluoride. After blood sampling, the nails were removed and the halves near to the growth end were immediately analyzed for fluoride. The right femur of each animal was also removed, cleaned of soft tissue and dried at $60^{\circ} \mathrm{C}$ until reaching a constant weight. Then a circular area $\left(4.52 \mathrm{~mm}^{2}\right)$ was isolated and the rest was covered with nail polish. The exposed area was immersed in $0.25 \mathrm{~mL}$ of $0.5 \mathrm{M} \mathrm{HCl}$ for 15 seconds under agitation and neutralized with $0.25 \mathrm{~mL} \mathrm{TISAB}^{2}$. The solution was then analyzed for phosphorus $^{12}$ and fluoride analysis in order to determine fluoride concentration (ppm).

\section{Fluoride analysis}

Nail samples were cleaned briefly with deionized water using a piece of cloth and then sonicated in deionized water for 10 minutes, dried at $60^{\circ} \mathrm{C}$ for 2 hours and weighed. The weight of the samples ranged from 5.55 to $11.45 \mathrm{mg}( \pm 0.01$ $\mathrm{mg}$ ). Nail fluoride concentrations were determined after overnight, HMDS (hexamethyldisiloxane) facilitated diffusion (Taves ${ }^{23}$ ) as modified by Whitford ${ }^{26}$ using the ionspecific electrode (Orion Research, model 9409) and a miniature calomel reference electrode (Accumet, \#13-62079) both coupled to a potentiometer (Orion Research, model EA 940). During the diffusion process, which was carried out at room temperature $\left(22 \pm 1^{\circ} \mathrm{C}\right)$, the solutions in the nonwettable Petri dishes (Falcon, No. 1007) were gently swirled on a rotary shaker. Fluoride standards were prepared in triplicate and diffused in the same manner as the nail samples. In addition, non-diffused standards were prepared using the same solutions $(0.05 \mathrm{~N} \mathrm{NaOH}, 0.20 \mathrm{~N}$ acetic acid) that were used to prepare the diffused standards and samples. The non-diffused standards were made to have exactly the same fluoride concentrations as the diffused standards. The comparison of the millivolt readings demonstrated that the fluoride in the diffused standards had been completely trapped and analyzed. Plasma fluoride concentration was analyzed in the same way.

As for femur, the acid extract, after neutralization, was analyzed using the fluoride ion-specific electrode (Orion Research, model 9609).

\section{Statistical Analysis}

The data were tested for statistically significant differences by ANOVA and Tukey's post hoc test. Regression analysis was used to correlate the administered fluoride doses with the respective measured fluoride concentration in plasma, nails and bone. Further regression analysis verified the relationship between fluoride concentration in plasma vs. bone and nails. The data are expressed as mean $\pm \mathrm{SD}$. The significance level was established at $5 \%$.

\section{RESULTS}

Table 1 shows the mean fluoride concentrations $( \pm \mathrm{SD})$ found in rat nails, plasma and femur ( $\mu \mathrm{g} / \mathrm{g}$ or $\mu \mathrm{g} / \mathrm{mL}$ ) after single-dose fluoride administration. Average fluoride concentrations ranged from 55.4 to $91.5 \mu \mathrm{g} / \mathrm{g}$; from 0.019 to $6.937 \mu \mathrm{g} / \mathrm{mL}$ and from 617 to $2,394 \mu \mathrm{g} / \mathrm{g}$ in nails, plasma and femur, respectively. ANOVA showed a statistically significant difference in nail fluoride concentrations ( $\mathrm{F}=$ $3.447 ; \mathrm{p}<0.05)$. Tukey's test revealed that any of the groups differed from control. Plasma fluoride concentrations differed 
between groups $(\mathrm{F}=14.789 ; \mathrm{p}<0.000001)$ and Tukey's test revealed that all groups, except group 2, differed from control. Femur surface fluoride concentrations also differed between groups ( $F=5.858 ; \mathrm{p}<0.0001)$, but only groups 4 and 7 differed from control.

Regression analysis (Table 2) showed a weak positive linear correlation between fluoride concentration in nails and the fluoride dose administered $(r=0.25, \mathrm{p}<0.05)$. Between plasma fluoride concentration $(\mu \mathrm{g} / \mathrm{mL})$ and the fluoride dose administered a strong, positive, linear correlation was found $(\mathrm{r}=0.736, \mathrm{p}<0.001)$. A positive correlation was also found between femur fluoride concentration and the fluoride dose administered $(\mathrm{r}=0.510, \mathrm{p}<0.0001)$. Weak correlations were also found between nails and plasma fluoride levels ( $\mathrm{r}=0.31$, $\mathrm{p}<0.05$ ) as well as between femur and plasma fluoride levels $(\mathrm{r}=0.503, \mathrm{p}<0.0001)$.

\section{DISCUSSION}

Bone tissue investigation furnishes the best biomarker for fluoride accumulation in the organism. Nevertheless, the intravital bone biopsy, as an invasive method, is not applicable in epidemiological studies. Thus, attention has been focused on the nails that constitute an easily accessible material being able to reflect the subchronic and chronic exposures of fluoride in the organism ${ }^{7,11,14,20,21,22,28}$. Whitford, et $a .^{28}$ (1999) proposed that fingernail fluoride is derived mainly from the systemic circulation, via the matrix (growth end) and that fluoride intake is reflected by the concentrations in fingernails. Based on this, it was hypothesized that fluoride assay in nails growth portion could be used in postmortem tests after acute fluoride poisoning.

However, the results shown in Table 1 indicate no dose response effect on nail fluoride concentrations after two hours of fluoride administration, but a weak positive correlation between the nails and plasma fluoride levels was found (Table 2). This suggests that nail fluoride concentrations are associated with a "latent period" during subchronic or chronic fluoride exposures before physiological responses are noted. Since a range of doses was used, which included some that were expected to cause spontaneous death of the rats (ca. 75 and $90 \mathrm{mg} / \mathrm{kg}$ body weight), they were killed two hours after administering fluoride in order to avoid spontaneous death of the animals. Thus, longer periods after fluoride administration would make it impossible to establish the intended correlation. Gruninger, et al. ${ }^{13}$ and Whitford, et al. ${ }^{27}$ reported, for rats, $\mathrm{LD}_{50}$ values of 98 and 85.5 (77.1-94.5) mg fluoride/kg, respectively. Hence, the possibility that waiting a longer time to kill the animals after fluoride administration would allow enough time for fluoride administered to be incorporated into their nails cannot be ruled out. In addition,

TABLE 1- Mean ( $\pm S D ; n=10$ ) fluoride concentration in rat nails, plasma and femur surface after single-dose fluoride administration ( $\mathrm{mg} / \mathrm{kg}$ body weight)

\begin{tabular}{clll}
\hline Fluoride dose $(\mathbf{m g} / \mathbf{K g})$ & Nails $(\mu \mathrm{g} / \mathbf{g})$ & Plasma $(\mu \mathrm{g} / \mathbf{m L})$ & Femur $(\mu \mathrm{g} / \mathbf{g})$ \\
\hline 0 & $68.7( \pm 12.8)^{\mathrm{a}, \mathrm{b}}$ & $0.019( \pm 0.010)^{\mathrm{b}}$ & $617( \pm 258)^{\mathrm{a}}$ \\
10 & $55.4( \pm 9.0)^{\mathrm{b}}$ & $1.562( \pm 0.893)^{\mathrm{b}, \mathrm{c}}$ & $1,096( \pm 839)^{\mathrm{a}, \mathrm{b}}$ \\
35 & $76.5( \pm 22.1)^{\mathrm{a}, \mathrm{b}}$ & $3.224( \pm 1.639)^{\mathrm{a}, \mathrm{c}}$ & $1,583( \pm 757)^{\mathrm{a}, \mathrm{b}, \mathrm{c}}$ \\
45 & $56.0( \pm 25.7)^{\mathrm{b}}$ & $3.857( \pm 1.864)^{\mathrm{a}, \mathrm{c}}$ & $1,734( \pm 916)^{\mathrm{b}, \mathrm{c}}$ \\
60 & $60.7( \pm 15.4)^{\mathrm{a}, \mathrm{b}}$ & $4.268( \pm 1.463)^{\mathrm{a}}$ & $1,567( \pm 549)^{\mathrm{a}, \mathrm{b}, \mathrm{c}}$ \\
75 & $91.5( \pm 30.5)^{\mathrm{a}}$ & $4.319( \pm 2.349)^{\mathrm{a}}$ & $1,444( \pm 809)^{\mathrm{a}, \mathrm{b}, \mathrm{c}}$ \\
90 & $75.8( \pm 24.3)^{\mathrm{a}, \mathrm{b}}$ & $6.937( \pm 2.859)^{\mathrm{d}}$ & $2,394( \pm 664)^{\mathrm{c}}$ \\
\hline
\end{tabular}

Values in the same column with the same superscripts are not statistically significant $(p<0.05)$.

TABLE 2- Correlation between fluoride concentration (ppm) in nails, femur, and plasma and fluoride dose administered (mg/kg body weight)

\begin{tabular}{llll}
\hline \multicolumn{1}{c}{$\mathbf{y}$} & \multicolumn{1}{c}{$\mathbf{r}$} & \multicolumn{1}{c}{ Equation } \\
\hline Nails & Dose & $0.250(p=0.038)$ & $\mathrm{y}=60.5+0.20 \mathrm{x}$ \\
Plasma & Dose & $0.736(p<0.001)$ & $\mathrm{y}=0.56+0.06 \mathrm{x}$ \\
Femur & Dose & $0.510(p<0.0001)$ & $\mathrm{y}=848.0+14.2 \mathrm{x}$ \\
Femur & Plasma & $0.503(p<0.0001)$ & $\mathrm{y}=938.3+160.2 \mathrm{x}$ \\
Nails & Plasma & $0.310(p<0.05)$ & $\mathrm{y}=59.7+2.8 \mathrm{x}$ \\
\hline
\end{tabular}


plasma fluoride levels at death were 82 and 365 fold higher than the control group for the lowest and highest doses, respectively. This means that more fluoride could be incorporated into the nails growth end if the death had been conducted later. Regarding the accuracy of the analytical method used, previous results from Whitford, et al. ${ }^{28}$ indicated that HMDS-facilitated diffusion completely separates fluoride from intact nail clippings. That way, the need for ashing or other preparative methods before nail fluoride analysis is obviated.

In this study, the rats were fed a diet containing 25.9 ppm total fluoride soluble in $1 \mathrm{M} \mathrm{HCl}$. In a previous study (Cury, et al. ${ }^{6}$, 2002), for rats receiving a low fluoride diet (around $3 \mathrm{ppm}$ ), the fluoride concentration in nails growth portion for 42-day-old control rats was $85 \pm 31 \mu \mathrm{g} / \mathrm{g}$, while for nail tips it was $8 \pm 5 \mu \mathrm{g} / \mathrm{g}$. This suggested that the growth portion of the rat nail has the ability to concentrate fluoride, even when its intake is low.

As for the femur surface fluoride concentration only the group that received $90 \mathrm{mg}$ fluoride/kg body weight was statistically different from the control. The other groups did not differ from each other. This suggests that, as for the nails, the surface bone needs more than 2 hours before measurable fluoride uptake occurs. In addition, the data also suggest that, in rats, two hours after administering fluoride, bone surface is a better indicator of acute exposure to fluoride than nails. This can be better understood by examining the data in Table 2. A positive correlation was found between fluoride in femur and fluoride dose administered ( $\mathrm{r}=0.510$, $\mathrm{p}<0.0001$ ) and between fluoride in femur and plasma fluoride concentration $(r=0.503, p<0.0001)$. The correlation between nail fluoride concentration and the fluoride dose administered, as well as between nail fluoride concentration and plasma fluoride concentration was weaker $(r=0.25$, $\mathrm{p}=0.038$ and $\mathrm{r}=0.31, \mathrm{p}<0.005$, respectively).

Broglio 4 showed an increase of fluoride concentration on rats bone surface after administering a single dose of fluoride. The author administered a dose of fluoride ranging between 10-90 mg/kg body weight and observed that the highest concentration on bone surface was found 24 hours after administration followed by a decrease over time. Bezerra de Menezes, et al. ${ }^{2}$ described a relationship between fluoride dose and bone fluoride concentration in rats. The authors found that the ratio fluoride concentration in periosteal bone/fluoride concentration in whole bone is a biomarker for acute fluoride toxicity.

\section{CONCLUSION}

The present data suggest that, two hours after acute fluoride administration, nails growth end and bone surface are not good indicators of exposure in rats, despite the data obtained for the bone surface were better. The present authors are conducting studies on which plasma, nail and femur samples are collected after longer periods following exposure to fluoride. If a good dose-response is obtained, nails growth end and/or bone surface fluoride analysis could be additional postmortem tests in cases of accidental or suicidal fluoride poisoning.

\section{ACKNOWLEDGEMENTS}

This work was supported by FAPESP(Grants n. 00/008266 and 00/1174-2). We thank Dr. José Roberto Pereira Lauris for the statistical analysis. We are grateful to Dr. Gary M. Whitford for introducing and teaching us the fluoride assay technique used in his laboratory. We also thank Dr. Ricardo Marins de Carvalho for his review of this manuscript.

\section{REFERENCES}

1- Arnow PM, Bland LA, Garcia-Houchins S, Fridkin S, Fellner SK, An outbreak of fatal fluoride intoxication in a long-term hemodialysis unit. Ann Inter Med 1994;121:339-4.

2- Bezerra de Menezes LM, Volpato MC, Rosalen PL, Cury JA. Bone as a biomarker of acute fluoride toxicity. Forensic Sci Int 2003; 137(2-3):209-14.

3- Bost RO, Springfield A. Fatal hydrofluoric acid ingestion: a suicide case report. J Anal Toxicol 1995;19:535-6.

4- Broglio LAZ. Kinetic study of the effect of plasma and bone fluoride on incorporation in dental enamel of rats previously exposed or not, submitted to a single dose. (Thesis, PhD in Oral Biology and Pathology), Piracicaba Dental School, Campinas State University; 1994. 71p.

5- Church LE. Fluorides: use with caution. MD Dent Assoc 1976; 19:106.

6- Cury AH, Roncari GP, Whitford GM, Granjeiro JM, Rosalen PL, Buzalaf MAR. Relationship between nail fluoride concentration and age in rats. Pesq Odontol Bras 2002;16(Suppl.):96.

7- Czarnowski W, Krechniak J. Fluoride in urine, hair and nails of phosphate fertilizer workers. Br J Ind Med 1990; 47:349-51.

8- Dukes MNG. Fluoride. In: Dukes MNG, ed. Side effects of drugs, Annual 4. Excerpta Medica; 1980. p. 354.

9- Eichler HG, Lenz K, Fuhrmann M, Hruby K. Accidental ingestion of NaF tablets by children: report of a poison control center and one case. Int J Clin Pharmacol Ther Toxicol 1982;20:334-8.

10- Ekstrand J. Fluoride metabolism. In: Ekstrand J, Fejerskov O, Silverstone LM, editors. Fluoride in Dentistry. Copenhagen: Munksgaard; 1996. p.55-68.

11- Feskanich D, Owusu W, Hunter DJ, Willett WC, Ascherio A, Spiegelman D, et al. Use of toenail fluoride levels as an indicator for the risk of hip and forearm fractures in women. Epidemiology 1998;9:412-6.

12- Fiske CH, Subarrow Y. The colorimetric determination of phosphorus. J Biol Chem 1925;66:375-400.

13- Gruninger SE, Clayton R, Chang S-B, Siew C, Acute oral toxicity of dentifrice fluorides in rats and mice [ abstract 1769]. J Dent Res 1988; 67(Sp. Issue):334.

14- Machoy Z. Effects of environment upon fluoride content in nails in children. Fluoride 1989;22:169-73. 
15- Menchel SM, Dunn WA. Hydrofluoric acid poisoning. Am J Forensic Med Pathol 1984; 5:45-8.

16- Mullins ME, Warden CR, Barnum DW. Pediatric death and fluoridecontaining wheel cleaner. Ann Emerg Med 1998;31:524-5.

17- Muriale L, Lee E, Genovese J, Trend S. Fatality due to acute fluoride poisoning following dermal contact with hydrofluoric acid in a palynology laboratory. Ann Occup Hyg 1996;40:705-10.

18- Raikhlin-Eisenkraft B, Nutenko I, Kniznik D, Merzel J, Lev A. Death from fluoro-silicate in floor polish. Harefuah 1994;126:2589 .

19- Randall BB, Fraser BJ. Peanut butter and fatal fluoride poisoning. A case of mistaken identity. Am J Forensic Med Pathol 1994;15:403 .

20- Schamschula RG, Sugar E, Un PSH, Toth K, Barmes BE, Adkins BL. Physiological indicators of fluoride exposure and utilization: An epidemiological study. Comm Dent Oral Epidemiol 1985;13:104-7.

21- Schmidt CW, Leuschke W. Fluoride content in finger nails taken from persons with and without chronic fluoride exposure. Fluoride 1980;23:79-82.

22- Spate VL, Morris JS, Baskett CK, Mason MM, Reams CL, Hunter DJ, et al. Determination of fluoride in human nails via cyclic neutral activation analysis. J Radioanalyt Nucl Chem 1994;179:27-33.

23- Taves DR. Determination of submicromolar concentrations of fluoride in biological samples. Talanta 1968;15:1015-23.

24- Tepperman PB. Fatality due to acute systemic fluoride poisoning following a hydrofluoric acid skin burn. J Occup Med 1980;22:691-2.

25- Watson AA, Oliver JS, Thorpe JW. Accidental death due to inhalation of hydrofluoric acid. Med Sci Law 1973;13:277-9.

26- Whitford GM. Some characteristics of fluoride analysis with the electrode. In: Myers HM, editor. The metabolism and toxicity of fluoride. 2nd ed. Basel: Karger; 1996. p.303-33.

27- Whitford GM, Birdsong-Whitford NL, Finidori C. Acute oral toxicity of sodium fluoride and monofluorophosphate separately or in combination in rats. Caries Res 1990;24: 561-9.

28- Whitford GM, Sampaio FC, Arneberg P, Von der Fehr FR, Fingernail fluoride: a method for monitoring fluoride exposure. Caries Res 1999;33:462-7.

29- Wiese J, Klug E. Poisoning with a wood preservative. Beitr Gerichtl Med 1989;47:103-6. 